\title{
Effects of foliar application of salicylic acid and nitric oxide in alleviating iron deficiency induced chlorosis of Arachis hypogaea $L$.
}

\author{
Jing Kong, Yuanjie Dong*, Linlin Xu, Shuang Liu and Xiaoying Bai
}

\begin{abstract}
Background: The aim of this experiment was to analyze the alleviation mechanism of exogenous salicylic acid (SA) and sodium nitroprusside (SNP, a nitric oxide donor) on peanut seedlings under Fe deficiency. The effects of SA and SNP on iron uptake and availability, ions balance and oxidant damage were studied with foliar application of exogenous $1.0 \mathrm{mM} \mathrm{SA}(\mathrm{SA})$ or $2.5 \mathrm{mM}$ SNP (SNP) or $0.5 \mathrm{mM}$ SA+1.25 mM SNP [1/2(SA+SNP)] or $1.0 \mathrm{mM} \mathrm{SA+2.5} \mathrm{mM} \mathrm{SNP} \mathrm{(SA+SNP).}$

Results: The results showed that after 21 days treatment, the peanut seedlings growing under iron deficiency conditions exhibited leaf interveinal chlorosis, and this iron-deficiency induced symptom was prevented by foliar application of SA, SNP, $1 / 2$ (SA+SNP), especially SA+SNP. The increased contents of chlorophyll and active iron, and increased Fe accumulation in cell organelles were observed in SA+SNP treated young leaves, suggesting that an improvement of iron availability in plants. Moreover, the improved nutrient solution $\mathrm{pH}$, increased $\mathrm{H}^{+}$-ATPase activity and increased iron concentration in roots in SA+SNP treated plants, suggesting that SA+SNP is effective in modulating iron uptake. Furthermore, the increased calcium (Ca), magnesium (Mg) and zinc (Zn) concentrations and decreased manganese ( $\mathrm{Mn}$ ) and copper (Cu) concentrations in the leaves and roots of peanut indicated that SA+SNP stimulated the maintenance of ions disturbed by Fe deficiency. In addition, SA+SNP alleviated the increased accumulation of superoxide anion $\left(\mathrm{O}_{2}{ }^{--}\right)$generation rate and malondialdehyde (MDA), and modulated the antioxidant enzymes.
\end{abstract}

Conclusions: These results indicated that the interaction of SA and SNP promoted Fe uptake, translocation and activation; modulated the balance of mineral elements; and protected Fe deficiency induced oxidative stress. Therefore, SA and SNP had synergistic effects in alleviating chlorosis induced by Fe deficiency.

Keywords: Active iron; Antioxidant enzymes; Arachis hypogaea L; Mineral elements; SA; SNP

\section{Background}

Iron $(\mathrm{Fe})$ is an essential mineral nutrient for plants. It acts as a co-factor for many enzymes and proteins. Fe is involved in chlorophyll biosynthesis, thylakoid synthesis, and chloroplast development (Buchanan et al. 2000). Therefore, Fe deficiency impairs chlorophyll biosynthesis and chloroplast development in both dicotyledonous and monocotyledonous species (Graziano et al. 2002). Additionally, in higher plants, it is well known that the retranslocation of Fe from old leaves to young leaves is difficult. Therefore, when the plants suffer from Fe deficiency, the newly forming leaves develop chlorosis

\footnotetext{
* Correspondence: yjdong@sdau.edu.cn

College of Resources and Environment, Shandong Agricultural University,
} Tai'an 271018, P.R. China

\section{Springer}

(c) 2014 Kong et al.; licensee Springer. This is an Open Access article distributed under the terms of the Creative Commons Attribution License (http://creativecommons.org/licenses/by/2.0), which permits unrestricted use, distribution, and reproduction in any medium, provided the original work is properly cited. symptoms (Jin et al. 2007). Peanuts belong to Strategy I plants, and it responds to Fe deficiency by absorbing iron in three successive steps. First, they acidify the rhizosphere to increase the solubility of $\mathrm{Fe}(\mathrm{III})$ (Santi and Schmidt 2009). Next, they reduced soluble Fe(III) to $\mathrm{Fe}(\mathrm{II})$ by the ferric-chelate reductase FRO2 (Ding et al. 2009). Finally, plants transport $\mathrm{Fe}(\mathrm{II})$ across the root plasma membrane by the metal transporter IRT1 (Ding et al. 2010). However, the factors that induced Fedeficiency chlorosis of peanut were very complicated in the field, and the best predictor of Fe efficiency in peanut was not very clear (Gao and Shi 2007).

Salicylic acid (SA) is an endogenous growth regulator of phenolic nature, which participates in the regulation of physiological processes and plant resistance to biotic and abiotic stress (Karlidag et al. 2009). For example, 
it improves germination, plant growth, transpiration rate, stomatal regulation and photosynthesis, ion uptake and transport (Khan et al. 2003; Metwally et al. 2003; Khodary 2004; He et al. 2010). Furthermore, it is now clear that SA provides protection against a number of abiotic stress as heat stress in strawberry (Karlidag et al. 2009), heavy metal stress such as cadmium (Metwally et al. 2003; He et al. 2010), copper (Khodary 2004; El-Tayeb 2006) and manganese (Shi and Zhu 2008), and salt stress (El-Tayeb 2005; Khodary 2004). In addition, it is becoming clear that SA interacts both negatively and positively with other major signaling pathways, including those regulated by jasmonic acid and ethylene (Raskin 1992). Furthermore, it is demonstrated that SA is able to trigger nitric oxide synthesis in Arabidopsis seedlings. Studying the kinetics of accumulation of nitric oxide, a clear response was observed that was dependent on the concentration of SA (Zottini et al. 2007).

Nitric oxide (NO) is another signaling molecule, which plays an important role in many physiological processes in plants, such as growth, development, senescence and adaptive responses to multiple stresses $(\mathrm{Hu}$ et al. 2007; Farooq et al. 2009; Kazemi et al. 2010). Recently, it has been shown that treatment with $\mathrm{NO}$ or its donor can mediate chlorophyll increase, Fe availability and antioxidant enzymes (Zhang et al. 2012). Several models suggest that redox signalling through NO and ROS is enhanced by SA in a self-amplifying process. However, the relationship between NO, SA, and ROS in the activation of defence genes and/or induction of host cell death is not clearly defined (Zottini et al. 2007).

Iron deficiency has been a widespread problem in peanut (Arachis hypogaea L.) grown on calcareous soils of northern China and has resulted in significant yield losses (Gao and Shi 2007). Previous researches demonstrated that the interaction of SA with SNP could counteract the deleterious effects induced by $\mathrm{NaCl}$ (Simaei et al. 2011). Based on the above studies, we suppose that $\mathrm{SA}$ and NO participates in Fe deficiency tolerance was important in peanut seedlings and the interaction of SA with NO could ameliorate Fe deficiency induced chlorosis. Therefore, the purpose of the present study was to examine whether foliar application of SA and SNP could (i) improve Fe uptake, transportation and activation; (ii) modulate the ions balance; (iii) protect Fe deficiency induced oxidative stress.

\section{Methods}

\section{Plant materials and experimental design}

The selected seeds of peanut (Arachis hypogaea L.) were surface sterilized with $5 \% \mathrm{H}_{2} \mathrm{O}_{2}$ for 30 min, washed several times with sterile deionized water, and germinated on wet sterile sand at $25^{\circ} \mathrm{C}$ in the darkness. After germination, uniform seedlings transferred into aerated one-half strength Hoagland solution for 3 days. Then, the solution was replaced with standard Hoagland solution (Hoagland and Arnon 1950). When the third leaf expanded fully, the seedlings were transferred into hydroponic systems (Hoagland nutrient solution which substituting $0.1 \mathrm{mM} \mathrm{FeSO}_{4}$ for $0.1 \mathrm{mM}$ EDTA-Fe) and removed cotyledons. Six treatments were established as follows: (1) hydroponic systems (CK); (2) Hoagland nutrient solution containing $0.1 \mathrm{mM}$ EDTA-Fe (EDTA-Fe); (3) hydroponic systems and foliar application of $1.0 \mathrm{mM}$ SA (SA); (4) hydroponic systems and foliar application of $2.5 \mathrm{mM}$ SNP (SNP); (5) hydroponic systems and foliar application of $1.0 \mathrm{mM} \mathrm{SA}$ and $2.5 \mathrm{mM}$ SNP (SA+SNP); (6) hydroponic systems and foliar application of $0.5 \mathrm{mM}$ $\mathrm{SA}$ and $1.25 \mathrm{mM}$ SNP $[1 / 2(\mathrm{SA}+\mathrm{SNP})]$. The treatments are arranged in a randomized block design with three replicates. Treatments of spraying SA and/or SNP solution on leaves were performed in the evening every day with $10 \mathrm{~mL}$ every time. Each pot had $2.5 \mathrm{~L}$ of aerated nutrient solution and contained four plants. Nutrient solutions were replaced every three days and initial $\mathrm{pH}$ value was adjusted to 6.3 with $1.0 \mathrm{mM} \mathrm{NaOH}$. Plants were grown in a growth chamber at $25 \pm 1^{\circ} \mathrm{C} / 20 \pm 1^{\circ} \mathrm{C}$ (day/night) temperatures with a $16 \mathrm{~h}$ photoperiod at a light intensity of $300 \pm 10 \mu \mathrm{Em}^{-2} \mathrm{~s}^{-1}$ provided by reflector sunlight dysprosium lamp. Relative humidity ranged from 65 to $70 \%$.

\section{Determination of Chlorophyll content, photosynthetic parameters and fluorescent parameters}

The chlorophyll content was determined according to the method of Knudson et al. (1977). $0.5 \mathrm{~g}$ fresh peanut leaves were extracted in $2 \mathrm{~mL} 95 \%(\mathrm{v} / \mathrm{v})$ ethanol for $24 \mathrm{~h}$ in the dark, and the extracted solution was analyzed. The amounts of chlorophyll $a, b$ and carotenoid were determined spectrophotometrically (SHIMADZU UV-2450, Kyoto, Japan), by reading the absorbance at 665, 649 and $470 \mathrm{~nm} . \mathrm{C}_{\mathrm{a}}=13.95^{*} \mathrm{~A} 665-$ 6.88*A649; $\mathrm{C}_{\mathrm{b}}=24.96 * \mathrm{~A} 649-7.32 * \mathrm{~A} 665 ; \mathrm{C}_{\text {carotenoid }}=$ (1000*A470-2.05* $\left.\mathrm{C}_{\mathrm{a}}-114.8 * \mathrm{C}_{\mathrm{b}}\right) / 245$. The chlorophyll content results are expressed as unit's mg per gram-fresh weight $\left(\mathrm{mg}^{-1} \mathrm{FW}\right)$.

The young leaves were selected to measure photosynthetic and fluorescent parameters between 9:00-10:00 AM by using the photosynthesis system (CIRAS-2, UK) and the pulse amplitude modulated system (model FMS2. Hansatech Instruments. UK).

\section{Determination of the nutrient solution $\mathrm{pH}$}

The nutrient solution $\mathrm{pH}$ was determined with a MV$\mathrm{pH}$ meter (DMP-2), and each treatment was replicated for three times. From the nineteen day after establishing Fe deficiency condition, in other words, from the last time change nutrient solutions, the nutrient solution $\mathrm{pH}$ 
was measured from 8 a.m. to 6 p.m. for every two hours in the first day (nineteen-day-old peanut seedlings), and measured at 2 p.m. in the second (twenty-day-old peanut seedlings) and third day (twenty one-day old seedlings). During the measuring period, the nutrient solution was not replaced, and only distilled water was added to replenish that lost by evaporation.

\section{Isolation of plasma membrane and the measurement of $\mathrm{H}^{+}$-ATPase and $\mathrm{Ca}^{2+}$-ATPase activities in PMs}

A membrane fraction enriched in plasma membrane vesicles was prepared as described by Briskin et al. (1987) with minor changes. Excised roots were homogenized $(1 / 2, w / v)$ with a mortar and pestle in a cold grinding medium containing: $25 \mathrm{mM}$ HEPES-Tris $(\mathrm{pH}$ 7.2), $250 \mathrm{mM}$ mannitol, $5 \mathrm{mM}$ EDTA, $5 \mathrm{mM}$ EGTA, $1 \mathrm{mM}$ DTT and $1.5 \%(\mathrm{w} / \mathrm{v})$ PVP. The whole isolation procedures were carried out at $4{ }^{\circ} \mathrm{C}$. The homogenate was filtered through four layers of cheesecloth and centrifuged at $560 \times \mathrm{g}$ for $12 \mathrm{~min}$, then the supernatant was centrifuged at $10,000 \times \mathrm{g}$ for $15 \mathrm{~min}$, and the supernatant was centrifuged at $60,000 \times \mathrm{g}$ for $30 \mathrm{~min}$ to yield a crude membrane fraction. The resulting pellet was resuspended with $1 \mathrm{~mL}$ in a gradient buffer containing: $20 \mathrm{mM}$ HEPES-Tris (pH 7.5), $5 \mathrm{mM}$ EDTA, $0.5 \mathrm{mM}$ EGTA. The supernatant was layered on top of a step

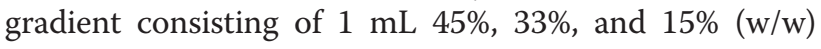
sucrose, respectively, and then centrifuged for $2 \mathrm{~h}$ at $70,000 \times$ g.

ATP hydrolysis assays were performed as described by Briskin et al. (1987) in $0.5 \mathrm{~mL}$ the reaction medium containing: $36 \mathrm{mM}$ Tris-Mes ( $\mathrm{pH}$ 6.5), $30 \mathrm{mM}$ ATP$\mathrm{Na}_{2}, 3 \mathrm{mM} \mathrm{MgSO}$, $1 \mathrm{mM} \mathrm{NaN}$, $50 \mathrm{mM} \mathrm{KNO}, 1 \mathrm{mM}$ $\mathrm{Na}_{2} \mathrm{MoO}_{4}, 0.02 \%(\mathrm{w} / \mathrm{v})$ Triton A-100, in the presence or absence of $2.5 \mathrm{mM} \mathrm{Na} \mathrm{VO}_{4}$. The reaction was started by adding $50 \mu \mathrm{L}$ PM vesicles. After 30 min incubation at $37^{\circ} \mathrm{C}$, the reaction was quenched by the addition of $50 \mu \mathrm{L} 55 \%(\mathrm{w} / \mathrm{v})$ TCA. The $\mathrm{H}^{+}$-ATPase activity was determined by measuring the release of $\mathrm{Pi}$ (Ohinishi et al. 1975).

Additionally, ATP hydrolysis assays were performed as described by Briskin et al. (1987) in $0.5 \mathrm{~mL}$ the reaction medium containing: $50 \mathrm{mM}$ Tris-Me (pH 7.6), $250 \mathrm{mM}$ sucrose, $1.0 \mathrm{mM}$ DTT, $2.0 \mathrm{mM}$ ATP-Na $2,0.1 \mathrm{mM}\left(\mathrm{NH}_{4}\right)_{2}$ $\mathrm{MoO}_{4}, 0.02 \%$ TritonX-100 (v/v), $300 \mathrm{Mm} \mathrm{NaNO}_{3}$, $1.0 \mathrm{mM} \mathrm{NaN}_{3}$, in the presence or absence of $2.0 \mathrm{mM}$ $\mathrm{Ca}\left(\mathrm{NO}_{3}\right)_{2}$. The reaction was started by adding $50 \mu \mathrm{L} \mathrm{PM}$ vesicles. After $30 \mathrm{~min}$ incubation at $37^{\circ} \mathrm{C}$, the reaction was quenched by the addition of $50 \mu \mathrm{L} 55 \%(\mathrm{w} / \mathrm{v})$ TCA. The $\mathrm{Ca}^{2+}$-ATPase activity was determined by measuring the release of Pi (Ohinishi et al. 1975).

Soluble protein content was measured by the Coomassie Brilliant Blue G-250 method (Bradford, 1976). Soluble protein content was expressed as $\mathrm{mg} \mathrm{g}^{-1} \mathrm{FW}$.

\section{Assay of $\mathrm{Fe}$ (III)-Chelate Reductase (FCR)}

Plants roots were immersed in saturated $\mathrm{CaSO}_{4}$ solution for $5 \mathrm{~min}$, washed with deionized water, and then transferred to the nutrient solution mentioned above, which contained $0.1 \mathrm{mM}$ Fe-EDTA and 0.4 mM 2, 2-bipyridyl, $\mathrm{pH}$ 5.0. The environmental conditions during the measurement were the same as for plant growth. After $2 \mathrm{~h}$, Fe-reduction capacity by the roots was determined by measuring the concentration of $\mathrm{Fe}^{2+}$-dipyridyl complex formed at $\mathrm{A}_{523}$ in a spectrophotometer (Shimadzm UV2210) (Gao and Shi 2007).

\section{Determination of active Fe content}

Fresh young leaves were cut into pieces and $2.00 \mathrm{~g}$ was weighed and extracted with $20 \mathrm{~mL} 1 \mathrm{~N} \mathrm{HCl}$ (in 1:10 tissue: extractant), shaken for $5 \mathrm{~h}$ and filtered, and the subsequent $\mathrm{Fe}$ concentration in the filtrate was measured with atomic absorption spectrophotometer (PE-2100B, Perkin Elmer Co. Ltd., MA, USA) (Gao and Shi 2007).

\section{Determination of the distribution of $\mathrm{Fe}$ in subcellular structure of peanut plants}

After 21 days of treatment, roots of all the peanut plants were immersed in $20 \mathrm{mM}$ disodium ethylenediamine tetraacetic acid $\left(\mathrm{Na}_{2}\right.$-EDTA) for $15 \mathrm{~min}$ and were then rinsed three times with deionized water. Each $25 \mathrm{~g}$ sample was homogenized in $50 \mathrm{~mL}$ of chilled extraction buffer containing $50 \mathrm{mM}$ Hepes (pH 7.5), $500 \mathrm{mM}$ sucrose, $1 \mathrm{mM}$ DTT, $5 \mathrm{mM}$ ascorbate and $1 \%$ polyvinylpolypyrrolidone (PVPP). The homogenate was centrifuged at $500 \times \mathrm{g}$ for $5 \mathrm{~min}$ to isolate the cell wall fraction. The supernatant from this centrifugation step was then centrifuged at $20,000 \times$ g for 45 min to sediment cell organelles, and the resultant supernatant solution was referred to as the soluble fraction. All steps were performed at $4^{\circ} \mathrm{C}$. The fractions of the samples were digested in a mixture of $\mathrm{HNO}_{3}$ and $\mathrm{HClO}_{4}(4: 1, \mathrm{v} / \mathrm{v})$ at $120^{\circ} \mathrm{C}$ for at least $3 \mathrm{~h}$. Fe was then quantified using an atomic absorption spectrometer (AA-6800, Shimadzu, Tokyo, Japan).

\section{Antioxidant enzymes and MDA extraction and assay}

For determination antioxidant enzymes, $0.5 \mathrm{~g}$ powder of freeze-dried peanut leaves were homogenized with $50 \mathrm{mM} \mathrm{Na} 2 \mathrm{HPO}_{4}-\mathrm{NaH}_{2} \mathrm{PO}_{4}$ buffer (pH 7.8) containing $0.2 \mathrm{mM}$ EDTA and $2 \%$ insoluble polyvinylpyrrolidone in a chilled pestle and mortar. The slurry was centrifuged at $12,000 \times \mathrm{g}$ for 20 minutes and the supernatant was used for enzyme activities assay. The experiment was carried out at $4^{\circ} \mathrm{C}$.

Total SOD activity was assayed by the photochemical method (Rao and Sresty 2000). The $3 \mathrm{~mL}$ reaction mixture contained $50 \mathrm{mM}$ phosphate buffer $(\mathrm{pH}$ 7.8), $13 \mathrm{mM}$ methionine, $75 \mu \mathrm{M}$ nitroblue tetrazolium, $2 \mathrm{mM}$ riboflavin, $10 \mathrm{mM}$ EDTA and $0.1 \mathrm{~mL}$ enzyme extract. 
One unit of the enzyme activity was defined as the amount of enzyme required to result in a $50 \%$ inhibition of the rate of nitro blue tetrazolium (NBT) reduction measured at $560 \mathrm{~nm}$. SOD activity was expressed as $\mathrm{U} \mathrm{g}^{-1}$ FW min $^{-1}$. Guaiacol peroxidase (POD) activity was estimated after Nickel and Cunningham (1969) method. Activity was measured by the increase in absorbance at $470 \mathrm{~nm}$ due to guaiacol oxidation. The activity was expressed as $\mathrm{U} \mathrm{g}^{-1} \mathrm{FW} \mathrm{min}^{-1}$. CAT activity was determined by following the consumption of $\mathrm{H}_{2} \mathrm{O}_{2}$ at $240 \mathrm{~nm}$ according to the method of Cakmak and Marschner (1992). CAT activity was expressed as nmol $\mathrm{H}_{2} \mathrm{O}_{2} \mathrm{mg}^{-1} \mathrm{FW} \mathrm{min}{ }^{-1}$. The level of lipid peroxidation in fresh leaf was measured in terms of malondialdehyde (MDA) content by the thiobarbituric acid reaction method (Heath and Packer 1968). MDA content was expressed as nmol g ${ }^{-1} \mathrm{FW}$.

\section{Determination of the $\mathrm{O}_{2}{ }^{--}$generation rate}

For the measurement of $\mathrm{O}_{2}{ }^{--}$germination rate, $0.3 \mathrm{~g}$ fresh leaves were ground in liquid $\mathrm{N}_{2}$ and extracted in $3 \mathrm{~mL}$ of ice cold $50 \mathrm{mM}$ sodium phosphate buffer (PBS) ( $\mathrm{pH}$ 7.0). One milliliter supernatant of fresh leaves extraction was added to $0.9 \mathrm{~mL} 65 \mathrm{mM}$ phosphate buffer solution ( $\mathrm{pH} 7.8$ ) and $0.1 \mathrm{~mL} 10 \mathrm{mM}$ hydroxylammoniumchloride. The reaction was incubated at $25^{\circ} \mathrm{C}$ for $35 \mathrm{~min}$. $0.5 \mathrm{~mL}$ solution from the above reaction mixture was then added in $0.5 \mathrm{~mL} 17 \mathrm{mM}$ sulfanic acid and $0.5 \mathrm{~mL} 7.8 \mathrm{mM}$ a-naphthylamine solution. After $20 \mathrm{~min}$ of reaction, $2 \mathrm{~mL}$ of ether was added into the above solution, and then mixed well. The solution was centrifuged at $1500 \times \mathrm{g}$ at $4^{\circ} \mathrm{C}$ for $5 \mathrm{~min}$. The absorbance of the pink supernatant was measured at $530 \mathrm{~nm}$ with the spectrophotometer. Absorbance values were calibrated to a standard curve generated with known concentrations of $\mathrm{HNO}_{2}$ (Shi and $\mathrm{Zhu}$ 2008).

\section{Determination of plant growth index and mineral element concentrations}

After 21 days treatment, the peanut plants were harvested. Roots were soaked in $20 \mathrm{mM} \mathrm{Na}$-EDTA for $15 \mathrm{~min}$ to remove metal ions adhering to root surfaces, and rinsed with deionized water several times. The peanut plants were divided into roots and shoots and measured plant height, root length and fresh weight. The root volume was determined by the water. The samples were dried at $70^{\circ} \mathrm{C}$ to constant weight and weighted. $50 \mathrm{mg}$ of dried plant tissues were ground up and digested in $1 \mathrm{~mL}$ of concentrated nitric acid for $2-3 \mathrm{~d}$ at room temperature. Samples were then boiled for 1-2 h until completely digested. After adding $4 \mathrm{~mL}$ of millipore-filtered deionized water and briefly centrifuging, the mineral element concentrations of each sample were determined by atomic absorption spectrophotometer (SHIMADZU AA-6300) (Zhang et al. 2011).

\section{Statistical analysis}

The tukey's test was used to test the effect of different treatment, and the least significant difference (LSD) was calculated to compare the difference between means in each treatment. Statistical analyses were performed by analysis of variance (ANOVA) using the SAS software and correlative analysis used the SPSS software (SPSS 11.5).

\section{Results}

\section{Plant growth}

Table 1 shows that plant growth characteristics of peanut were greatly influenced by Fe deficiency and foliar application of SA and/or SNP. Fe deficiency dramatically decreased the shoot height, fresh weight and root/shoot ratio. However, addition of SA, SNP, especially SA+SNP alleviated the Fe deficiency effects. When peanut plants were treated with SA or SNP under Fe deficiency, the shoot height, root length and root volume in SA treatment increased by $18.2 \%, 29.3 \%$ and $19.4 \%$ compared with control, and the fresh weight and root/shoot ratio in SNP treatment increased by $28.4 \%$ and $33.3 \%$ compared with control. In addition, the alleviation effect of SA+SNP was detected best compared with SA, SNP or $1 / 2(\mathrm{SA}+\mathrm{SNP})$ treatment.

\section{Chlorophyll content}

As shown in Table 2, there was a significant decrease on chlorophyll content of peanut plants under Fe deficiency. However, foliar application of SA, SNP, 1/2(SA+SNP), especially $\mathrm{SA}+\mathrm{SNP}$, the inhibitory effects of Fe deficiency on chl $a$ and chl $b$ were significantly ameliorated. Additionally, foliar application of SA+SNP dramatically increased the chl $a+b$, car and chl $a / b$ ratio by $19.1 \%, 26.3 \%$ and $3.6 \%$ compared with control, respectively.

\section{Photosynthetic and fluorescent parameters}

Peanut plants subjected to Fe deficiency exhibited a dramatic decrease in net photosynthetic $(P n)$ and transpiration rates $(\operatorname{Tr})$ by $32.9 \%$ and $23.5 \%$ compared with EDTA-Fe treatment, whereas Fo, Fv/Fm and ФPSII also significantly decreased in peanut leaves (Table 3 ). However, when peanut plants treated with $\mathrm{SA}, \mathrm{SNP}, 1 / 2(\mathrm{SA}+\mathrm{SNP})$, particularly SA+SNP, the inhibition of photosynthetic system induced by Fe deficiency remarkably alleviated. In addition, the Fo, Fv/Fm and $\Phi$ PSII of SA+SNP treatment, interestingly increased by $26.55 \%, 8.6 \%$ and $26.9 \%$ compared with control, and the Fv/Fm and ФPSII were similar to EDTA-Fe treated ones.

\section{The $\mathrm{pH}$ of nutrient solution and the activities of $\mathrm{H}^{+}$-ATPase and $\mathrm{Ca}^{2+}$-ATPase}

The $\mathrm{H}^{+}$-ATPase transports protons out of the cell across the plasma membrane, thus establishing the proton electrochemical gradient that contributes to the maintenance 
Table 1 Effects of exogenous SA and NO on plant growth of peanut at 21 days treatment

\begin{tabular}{cccccc}
\hline Treatments & Shoot height (cm/plant) & Root length (cm/plant) & Root volume (mL/plant) & Fresh weight (g/plant) & Root/Shoot ratio \\
\hline CK & $28.60 \pm 0.66 \mathrm{c}$ & $8.53 \pm 0.06 \mathrm{~d}$ & $0.98 \pm 0.08 \mathrm{~d}$ & $6.17 \pm 0.08 \mathrm{~d}$ & $0.18 \pm 0.01 \mathrm{~d}$ \\
EDTA-Fe & $33.90 \pm 0.36 \mathrm{~b}$ & $9.63 \pm 0.78 \mathrm{~d}$ & $1.31 \pm 0.01 \mathrm{~b}$ & $7.05 \pm 0.70 \mathrm{c}$ & $0.21 \pm 0.01 \mathrm{c}$ \\
SA & $33.80 \pm 0.79 \mathrm{~b}$ & $11.03 \pm 1.23 \mathrm{c}$ & $1.17 \pm 0.06 \mathrm{c}$ & $7.50 \pm 0.66 \mathrm{bc}$ & $0.22 \pm 0.01 \mathrm{bc}$ \\
SNP & $34.33 \pm 0.46 \mathrm{~b}$ & $11.67 \pm 0.38 \mathrm{bc}$ & $1.18 \pm 0.07 \mathrm{c}$ & $7.90 \pm 0.29 \mathrm{ab}$ & $0.24 \pm 0.01 \mathrm{~b}$ \\
SA+SNP & $36.77 \pm 0.57 \mathrm{a}$ & $13.23 \pm 0.32 \mathrm{a}$ & $1.49 \pm 0.05 \mathrm{a}$ & $8.29 \pm 0.23 \mathrm{a}$ & $0.26 \pm 0.01 \mathrm{a}$ \\
$1 / 2($ SA+SNP) & $34.50 \pm 0.46 \mathrm{~b}$ & $12.73 \pm 0.59 \mathrm{ab}$ & $1.37 \pm 0.08 \mathrm{~b}$ & $8.16 \pm 0.13 \mathrm{ab}$ & $0.25 \pm 0.01 \mathrm{a}$
\end{tabular}

CK: hydroponic systems; EDTA-Fe: Hoagland nutrient solution containing $0.1 \mathrm{mM}$ EDTA-Fe; SA: hydroponic systems and foliar application of 1.0 mM SA; SNP: hydroponic systems and foliar application of $2.5 \mathrm{mM}$ SNP; SA+SNP: hydroponic systems and foliar application of $1.0 \mathrm{mM}$ SA and $2.5 \mathrm{mM}$ SNP; $1 / 2$ (SA+SNP): hydroponic systems and foliar application of $0.5 \mathrm{mM} \mathrm{SA}$ and $1.25 \mathrm{mM}$ SNP. Different lower case letters in the same line indicate a significant difference $(\mathrm{P}<0.05)$ between different treatments. Data are means \pm SD of three replicate samples per treatment.

of the intracellular and extracellular $\mathrm{pH}$ and plays a major role in the activation of ion and nutrient transport (Frédéric et al. 2007). Therefore, we determined the activities of $\mathrm{H}^{+}$-ATPase and $\mathrm{Ca}^{2+}$-ATPase in plasma membrane and $\mathrm{pH}$ of nutrient solution. As shown in Figure 1, under Fe deficiency, the activity of $\mathrm{H}^{+}$-ATPase was considerably stimulated. Compared with the control, SA+SNP and 1/2 $(\mathrm{SA}+\mathrm{SNP})$ treatments further increased the activity of $\mathrm{H}^{+}$-ATPase by $24.39 \%$ and $13.88 \%$, respectively. Fe deficiency inhibited the activity of $\mathrm{Ca}^{2+}$-ATPase. However, the $\mathrm{Ca}^{2+}$-ATPase activity was significantly increased by foliar application of SA, SNP, or $1 / 2(\mathrm{SA}+\mathrm{SNP})$, especially $\mathrm{SA}+\mathrm{SNP}$. In addition, as shown in Figure $1 \mathrm{C}$ and $\mathrm{D}$, on the whole, the nutrient solution $\mathrm{pH}$ of all treatments exhibited a decline from 8 a.m. to 14 p.m. in the first day, although it appeared to fluctuate in the decline. Under Fedeficiency stress, $\mathrm{pH}$ value in nutrient solution was significantly lower than EDTA-Fe treatment. SA+SNP treatment, in particular, showed the lowest $\mathrm{pH}$ at 14 p.m. in the first day. Furthermore, on the whole, the nutrient solution $\mathrm{pH}$ of all treatments exhibited a decline from the first day to the second day, and an increase from the second day to the third day (Figure 1B).

Total Fe, active Fe and FCR activity

As shown in Table 4, Fe deficiency inhibited Fe absorption and transportation of peanut seedlings, producing a $38.4 \%$ (roots), a $31.3 \%$ (stems) and a $19.5 \%$ (leaves) decrease in the Fe concentrations compared with EDTAFe treatment. Moreover, it markedly decreased the active Fe content. However, it strikingly increased FCR activity compared with EDTA-Fe treatment. Foliar application of SA, SNP or $1 / 2(\mathrm{SA}+\mathrm{SNP})$, particularly $\mathrm{SA}+\mathrm{SNP}$ showed a positive influence on Fe concentrations, active Fe content, and FCR activity. SA+SNP significantly increased the $\mathrm{Fe}$ concentrations in roots, stems and leaves by $37.68 \%, 55.40 \%$ and $111.75 \%$, and dramatically increased the active Fe content and FCR activity by $91.5 \%$ and $28.2 \%$, respectively, compared with control.

\section{The distribution of Fe in subcellular structure of peanut plants}

In order to investigate the mechanisms of exogenous SA and SNP in alleviating chlorosis induced by Fe deficiency, Fe distributions in cell wall, soluble fraction and cell organelles were examined carefully. In the roots, majority of Fe accumulated in the cell wall. However, Fe accumulated in the soluble fraction was less than in the cell wall, and only a minority of Fe accumulation was in cell organelles (Figure 2A). In contrast, in the leaves, the amount of $\mathrm{Fe}$ accumulated in the soluble fraction was more than the amount of Fe accumulated in the cell wall, and the cell organelles accumulated the least Fe

Table 2 Effects of exogenous SA and NO on $c h l a, c h l b, c a r, c h l ~ a+b$ and $c h l a / b$ of peanut

\begin{tabular}{|c|c|c|c|c|c|}
\hline Treatments & $\mathrm{Chl} a\left(\mathrm{mg} \mathrm{g}^{-1} \mathrm{FW}\right)$ & $\mathrm{Chl} b\left(\mathrm{mg} \mathrm{g}^{-1} \mathrm{FW}\right)$ & Carotenoids $x . c\left(\mathrm{mg} \mathrm{g}^{-1} \mathrm{FW}\right)$ & $\mathrm{Chl} a+b\left(\mathrm{mg} \mathrm{g}^{-1} \mathrm{FW}\right)$ & $\mathrm{Chl} a / b$ \\
\hline CK & $1.15 \pm 0.010 f$ & $0.46 \pm 0.003 d$ & $0.19 \pm 0.010 b$ & $1.62 \pm 0.010 f$ & $2.49 \pm 0.022 b$ \\
\hline EDTA-Fe & $1.22 \pm 0.003 e$ & $0.48 \pm 0.002 c$ & $0.20 \pm 0.009 a b$ & $1.70 \pm 0.005 e$ & $2.51 \pm 0.008 \mathrm{ab}$ \\
\hline SA & $1.26 \pm 0.001 d$ & $0.50 \pm 0.004 b c$ & $0.20 \pm 0.011 \mathrm{ab}$ & $1.76 \pm 0.005 d$ & $2.53 \pm 0.018 \mathrm{ab}$ \\
\hline SNP & $1.29 \pm 0.011 \mathrm{c}$ & $0.51 \pm 0.020 b$ & $0.21 \pm 0.028 \mathrm{ab}$ & $1.79 \pm 0.025 c$ & $2.55 \pm 0.098 \mathrm{ab}$ \\
\hline SA+SNP & $1.39 \pm 0.006 a$ & $0.54 \pm 0.004 a$ & $0.24 \pm 0.011 \mathrm{a}$ & $1.93 \pm 0.004 a$ & $2.58 \pm 0.031 \mathrm{a}$ \\
\hline $1 / 2(S A+S N P)$ & $1.35 \pm 0.005 b$ & $0.53 \pm 0.003 a$ & $0.22 \pm 0.032 \mathrm{a}$ & $1.88 \pm 0.002 b$ & $2.56 \pm 0.023 \mathrm{ab}$ \\
\hline
\end{tabular}

CK: hydroponic systems; EDTA-Fe: Hoagland nutrient solution containing $0.1 \mathrm{mM}$ EDTA-Fe; SA: hydroponic systems and foliar application of $1.0 \mathrm{mM}$ SA; SNP: hydroponic systems and foliar application of $2.5 \mathrm{mM} \mathrm{SNP}$; SA+SNP: hydroponic systems and foliar application of $1.0 \mathrm{mM}$ SA and $2.5 \mathrm{mM}$ SNP; $1 / 2(\mathrm{SA}+\mathrm{SNP})$ : hydroponic systems and foliar application of $0.5 \mathrm{mM}$ SA and $1.25 \mathrm{mM}$ SNP. Different lower case letters in the same line indicate a significant difference $(P<0.05)$ between different treatments. Data are means \pm SD of three replicate samples per treatment. 
Table 3 Effects of exogenous SA and NO on the net photosynthetic (Pn), transpiration rate (Tr), Fo, Fv/Fm and ФPSII of leaves

\begin{tabular}{|c|c|c|c|c|c|}
\hline Treatments & Pn $\left[\mu \mathrm{mol} \mathrm{m} \mathrm{m}^{-2} \cdot \mathrm{s}^{-1}\right]$ & $\operatorname{Tr}\left[\mathrm{mmol} \mathrm{m}{ }^{-2 \cdot} \mathrm{s}^{-1}\right]$ & Fo & $\mathrm{Fv} / \mathrm{Fm}$ & ФPSII \\
\hline CK & $10.78 \pm 1.14 \mathrm{e}$ & $0.88 \pm 0.11 \mathrm{e}$ & $82.44 \pm 1.71 \mathrm{C}$ & $0.805 \pm 0.04 b$ & $0.439 \pm 0.02 c$ \\
\hline EDTA-Fe & $16.07 \pm 0.98 d$ & $1.15 \pm 0.03 d$ & $95.78 \pm 0.69 b$ & $0.873 \pm 0.04 a$ & $0.535 \pm 0.02 a$ \\
\hline SA & $18.65 \pm 0.86 c$ & $1.64 \pm 0.07 c$ & $97.78 \pm 1.07 b$ & $0.843 \pm 0.04 a b$ & $0.483 \pm 0.01 b$ \\
\hline SNP & $18.72 \pm 0.85 c$ & $1.79 \pm 0.22 c$ & $97.67 \pm 0.58 b$ & $0.858 \pm 0.01 a$ & $0.468 \pm 0.02 b$ \\
\hline$S A+S N P$ & $24.89 \pm 1.24 a$ & $4.26 \pm 0.15 a$ & $104.33 \pm 3.79 a$ & $0.874 \pm 0.01 a$ & $0.557 \pm 0.02 \mathrm{a}$ \\
\hline $1 / 2(S A+S N P)$ & $24.82 \pm 0.65 b$ & $3.99 \pm 0.18 b$ & $100.33 \pm 4.51 \mathrm{ab}$ & $0.865 \pm 0.01 \mathrm{a}$ & $0.466 \pm 0.01 b c$ \\
\hline
\end{tabular}

CK: hydroponic systems; EDTA-Fe: Hoagland nutrient solution containing $0.1 \mathrm{mM}$ EDTA-Fe; SA: hydroponic systems and foliar application of $1.0 \mathrm{mM}$ SA; SNP: hydroponic systems and foliar application of $2.5 \mathrm{mM}$ SNP; SA+SNP: hydroponic systems and foliar application of $1.0 \mathrm{mM}$ SA and 2.5 mM SNP; 1/2(SA+SNP): hydroponic systems and foliar application of $0.5 \mathrm{mM}$ SA and $1.25 \mathrm{mM}$ SNP. Different lower case letters in the same line indicate a significant difference $(P<0.05)$ between different treatments. Data are means \pm SD of three replicate samples per treatment.

(Figure 2B). The results were quite different in the plants treated with Fe deficiency and foliar application of SA+SNP. Under Fe deficiency, Fe concentrations were significantly increased in the cell wall, but dramatically decreased in the cell organelle and soluble fraction in the roots and leaves of peanut. Foliar application of SA+SNP, Fe concentrations in the roots and leaves were interestingly increased in the cell organelle and soluble fraction, but decreased in the cell wall. In addition, the effect of $\mathrm{SA}+\mathrm{SNP}$ was better than $1 / 2(\mathrm{SA}+\mathrm{SNP})$.

\section{Antioxidant enzymes, MDA and $\mathrm{O}_{2}{ }^{--}$generation rate}

Results in Table 5 demonstrated that Fe deficiency led to the MDA content and $\mathrm{O}_{2}{ }^{--}$generation rate increased dramatically in the cells of peanut leaves. Foliar application of SA and/or SNP, the oxidative damage induced by $\mathrm{Fe}$ deficiency was significantly alleviated. As we all know, SOD, POD and CAT are all important antioxidant enzymes. Foliar application of SA, SNP, or $1 / 2(\mathrm{SA}+\mathrm{SNP})$, especially $\mathrm{SA}+\mathrm{SNP}$, significantly increased the activities of these enzymes. Foliar application of SA+SNP significantly increased the activities of SOD, POD and CAT by $9.32 \%, 113.3 \%$ and $22.41 \%$, respectively, compared with control.

\section{Mineral element contents}

As shown in Figure 3, Fe deficiency dramatically disturbed the ionic homeostasis, leading to the concentrations of manganese $(\mathrm{Mn})$, copper $(\mathrm{Cu})$ and zinc $(\mathrm{Zn})$ significantly increased, and the concentration of magnesium $(\mathrm{Mg})$ interestingly decreased in roots. Foliar application of SA and/or SNP, the concentrations of $\mathrm{Cu}$ and Mn significantly decreased, however, the concentrations of $\mathrm{Zn}$ and $\mathrm{Mg}$ dramatically increased in the roots and leaves compared with control. SA+SNP increased the concentrations of potassium (K), $\mathrm{Mg}$, calcium (Ca) and Zn by $11.4 \%, 85.9 \%, 30.6 \%$ and $19.0 \%$, and decreased the concentrations of $\mathrm{Cu}$ and $\mathrm{Mn}$ by $53.1 \%$ and $34.9 \%$ compared with control in the leaves of peanut.

\section{Discussion}

Symptoms of Fe deficiency in peanut have been previously described by Zuo et al. (2000). For example, Fe deficiency can cause decreased growth, alter photosynthetic rates and cause morphological changes in the leaves (Sun et al. 2007; Zhang et al. 2012). In this experiment, Fe deficiency-induced chlorophyll and carotenoids deficiency was closely correlated with visual observations of chlorosis of peanut leaves (Table 2), and similar results have been obtained in many other crop plants, such as pear (Morales et al. 2000), peach (Molassiotis et al. 2005), maize (Sun et al. 2007), and Chinese cabbage (Ding et al. 2008). The chlorosis can be ascribed to the role of $\mathrm{Fe}$ in the formation of $\delta$-aminolevulinic acid and protochlorophyllide, the precursors of the chlorophyll biosynthesis. In addition, Fe deficiency led to an inhibitory effect on plant growth (Table 1). The inhibition of growth in peanut might be resulted from Fe deficiency-induced alteration of fundamental metabolic process, photosynthesis, active Fe content and uptake of nutrient elements.

SA and NO are participating in the regulation of multiple physiological processes and plant resistance to biotic and abiotic stress. Recently, it was established that NO elevates the content of SA known as a component of signaling pathways during biotic stresses (Klessig et al. 2000) and SA may in turn stimulate synthesis of $\mathrm{NO}$ in Arabidopsis thaliana, acting via the enzyme with NO synthesizing activity (Zottini et al. 2007). The effects of SA and $\mathrm{NO}$ on alleviating environment toxicity in plants, such as nickel and salt stress, has been reported by Kazemi et al. (2010) and Simaei et al. (2011). Therefore, in the experiment, we analyzed the possible role of foliar application of SA and/or SNP in modulation of the photosynthetic performance and the antioxidant defense system against Fe deficiency induced chlorosis in peanut seedlings. Results from this experiment clearly indicated that SA, SNP, particularly SA+SNP, effectively alleviated chlorosis induced by Fe deficiency, described as SA and 


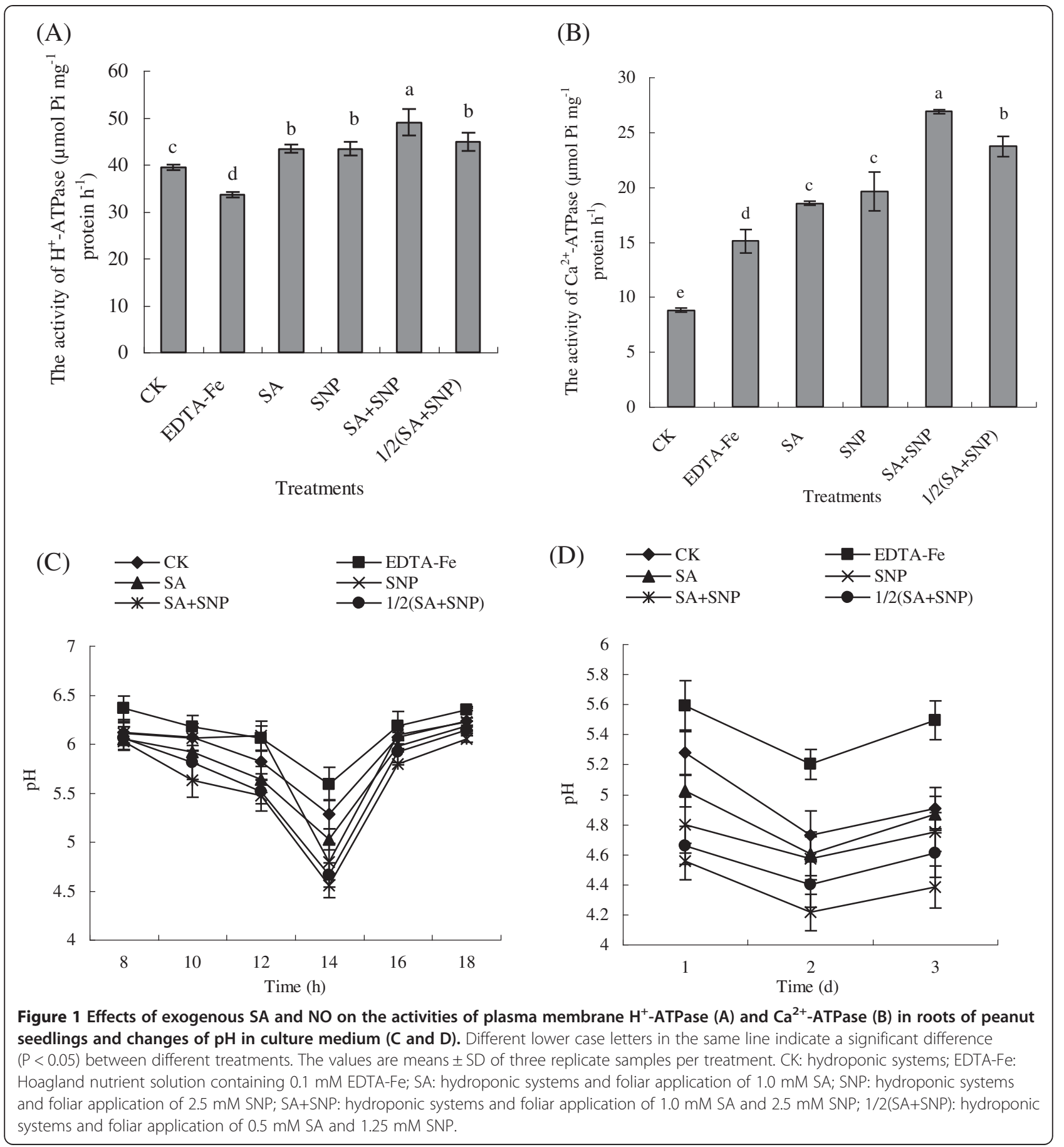

SNP increased the uptake and translocation of $\mathrm{Fe}$, promoted the activation of $\mathrm{Fe}$ in the leaves of peanut and protected Fe deficiency induced oxidative stress, resulting in increased chlorophyll content and improved seedling growth.

A notable reduction of chlorophyll parameters was detected in peanut seedlings exposed to Fe deficiency stress (Table 2; Zhang et al. 2012). The decrease in chlorophyll content might be attributed to Fe deficiency reduced active $\mathrm{Fe}$ content (Table 4), where active Fe participates in various physiological actions inside the plants, such as the electron transport, chlorophyll biosynthesis (Hakan and Vahap 2007; Zhang et al. 2011). Foliar application of SA, SNP, or $1 / 2(\mathrm{SA}+\mathrm{SNP})$, especially $\mathrm{SA}+\mathrm{SNP}$ to plants significantly enhanced the chlorophyll content in young leaves (Table 2; Kazemi et al. 2010). This phenomenon may be attributed to the fact that foliar application of SA and/or SNP decreased 
Table 4 Effects of exogenous SA and NO on the Fe concentration, active Fe content and Fe (III)- chelate reductase activity

\begin{tabular}{|c|c|c|c|c|c|}
\hline \multirow[t]{2}{*}{ Treatments } & \multicolumn{3}{|c|}{ Fe concentration ( $\left.\mathrm{mg} \mathrm{kg}^{-1} \mathrm{DW}\right)$} & \multirow{2}{*}{$\begin{array}{l}\text { Active Fe content } \\
\left(\mathrm{mg} \mathrm{kg}^{-1} \mathrm{FW}\right)\end{array}$} & \multirow{2}{*}{$\begin{array}{c}\mathrm{Fe}(\mathrm{III})-\text { chelate } \\
\text { reductase acticity } \\
\left(\mu \mathrm{mol} \mathrm{g}^{-1} 2 \mathrm{~h}^{-1} \mathrm{FW}\right)\end{array}$} \\
\hline & Roots & Stems & Leaves & & \\
\hline CK & $852.07 \pm 2.92 \mathrm{e}$ & $118.33 \pm 9.09 d$ & $125.11 \pm 9.20 \mathrm{e}$ & $33.45 \pm 1.10 f$ & $3.12 \pm 0.09 d$ \\
\hline EDTA-Fe & $1382.71 \pm 8.49 a$ & $172.34 \pm 8.52 b$ & $155.36 \pm 2.48 d$ & $50.02 \pm 0.81 e$ & $2.82 \pm 0.09 e$ \\
\hline SA & $865.35 \pm 18.99 e$ & $160.84 \pm 4.47 c$ & $159.24 \pm 9.64 d$ & $51.56 \pm 0.25 d$ & $3.35 \pm 0.02 c$ \\
\hline SNP & $916.50 \pm 2.89 d$ & $168.33 \pm 4.62 \mathrm{bc}$ & $183.34 \pm 5.20 c$ & $53.42 \pm 0.56 c$ & $3.37 \pm 0.07 c$ \\
\hline SA+SNP & $1173.14 \pm 12.91 b$ & $183.89 \pm 4.61 a$ & $264.92 \pm 4.63 a$ & $64.06 \pm 0.49 a$ & $4.00 \pm 0.12 a$ \\
\hline $1 / 2(S A+S N P)$ & $1022.90 \pm 8.78 c$ & $173.96 \pm 5.12 \mathrm{ab}$ & $227.15 \pm 9.77 b$ & $61.30 \pm 0.70 b$ & $3.74 \pm 0.06 b$ \\
\hline
\end{tabular}

CK: hydroponic systems; EDTA-Fe: Hoagland nutrient solution containing $0.1 \mathrm{mM}$ EDTA-Fe; SA: hydroponic systems and foliar application of 1.0 mM SA; SNP: hydroponic systems and foliar application of $2.5 \mathrm{mM} \mathrm{SNP}$; SA+SNP: hydroponic systems and foliar application of $1.0 \mathrm{mM}$ SA and $2.5 \mathrm{mM}$ SNP; $1 / 2$ (SA+SNP): hydroponic systems and foliar application of $0.5 \mathrm{mM} \mathrm{SA}$ and $1.25 \mathrm{mM}$ SNP. Different lower case letters in the same line indicate a significant difference $(P<0.05)$ between different treatments. Data are means \pm SD of three replicate samples per treatment.

chlorophyll degradation caused by senescence and environmental stress. In addition, foliar application of $\mathrm{SA}+\mathrm{SNP}$, the active Fe content was dramatically increased in leaves (Table 4) and the Fe concentration in the cell organelle in leaves was also significantly increased (Figure 2). It indicated that SA+SNP can improve Fe enter into cell and promote the activation of $\mathrm{Fe}$ in the leaves of peanut. The production of NO has been considered as an early response to iron deprivation and is maintained while the plant is exposed to low-iron conditions (Graziano and Lamattina 2007). Chen et al. (2010) further demonstrated that $\mathrm{NO}$ acts as a signal downstream of the auxin under Fe deficiency that leads to the ultimate induction of FCR via FIT-mediated transcriptional regulation. Peanuts belong to Strategy I plants respond to Fe deficiency by inducing the ferric chelate reductase embedded in root epidermal cell plasma membrane and also via stimulation of the plasma membrane proton pump, thus increasing proton exudation (Vert et al. 2002; Jin et al. 2006). Therefore, the increased active $\mathrm{Fe}$ content may be because SA+SNP enhanced excretion of protons and increased activity of FCR to solubilize $\mathrm{Fe}^{\mathrm{III}}$ oxides to $\mathrm{Fe}^{\mathrm{II}}$ chelates. The export of protons from the plant cells is mediated by the plasma membrane $\mathrm{H}^{+}$-ATPase (Ligaba et al. 2004; Osses and Godoy 2006). One of the main functions of plasmalemma $\mathrm{H}^{+}$-ATPase is $\mathrm{H}^{+}$extrusion from cell cytosol to cell wall area and loosening of cell wall microfibriles leading to cell growth by elongation (Hager 2003). These processes can be controlled by IAA and fusicoccine and

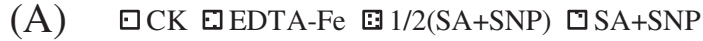

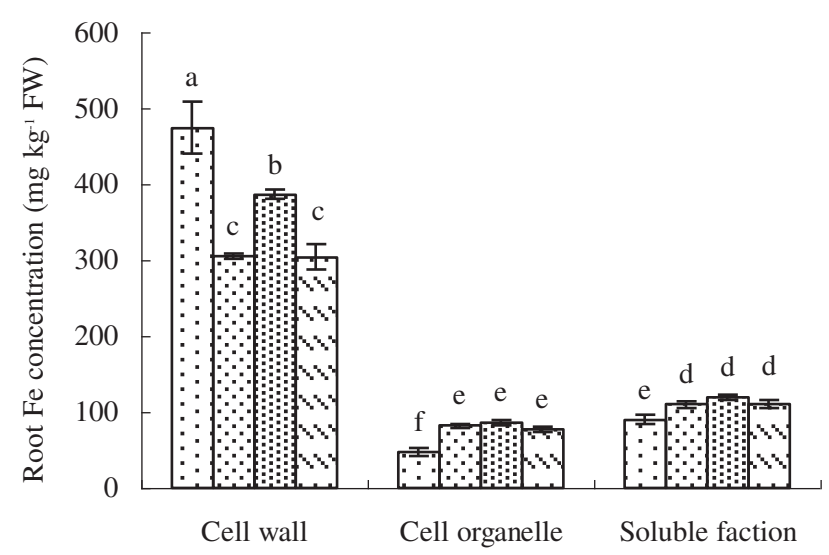

(B)

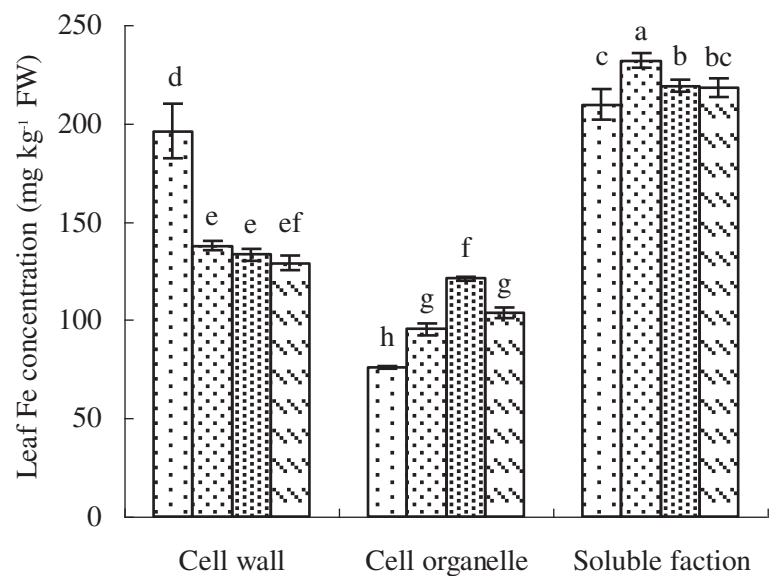

Figure 2 Effects of different treatments on tissue distribution of Fe in peanut roots (A) or leaves (B). Different lower case letters in the same line indicate a significant difference $(P<0.05)$ between different treatments. The values are means \pm SD of three replicate samples per treatment. CK: hydroponic systems; EDTA-Fe: Hoagland nutrient solution containing 0.1 mM EDTA-Fe; SA: hydroponic systems and foliar application of 1.0 mM SA; SNP: hydroponic systems and foliar application of 2.5 mM SNP; SA+SNP: hydroponic systems and foliar application of $1.0 \mathrm{mM} \mathrm{SA}$ and $2.5 \mathrm{mM} \mathrm{SNP;}$ 1/2(SA+SNP): hydroponic systems and foliar application of $0.5 \mathrm{mM}$ SA and $1.25 \mathrm{mM}$ SNP. 
Table 5 Effects of exogenous SA and NO on SOD, POD and CAT activities and MDA content and superoxide produce rate of peanut leaves

\begin{tabular}{|c|c|c|c|c|c|}
\hline Treatments & $\begin{array}{c}\text { SOD activity } \\
\text { (Unit } \mathrm{mg}^{-1} \text { protein) }\end{array}$ & $\begin{array}{c}\text { POD activity } \\
\text { (Unit } \mathrm{mg}^{-1} \text { protein) }\end{array}$ & $\begin{array}{c}\text { CAT activity } \\
\text { (Unit } \mathrm{g}^{-1} \text { protein) }\end{array}$ & $\begin{array}{l}\text { MDA content } \\
\left(\mathrm{nmol} \mathrm{g}^{-1} \mathrm{FW}\right)\end{array}$ & $\begin{array}{c}\mathrm{O}_{2}^{-} \text {generation rate } \\
\left(\mu \mathrm{mol} \mathrm{g}{ }^{-1} h^{-1} \mathrm{FW}\right)\end{array}$ \\
\hline CK & $2.36 \pm 0.08 b$ & $0.30 \pm 0.04 d$ & $0.058 \pm 0.003 c$ & $34.12 \pm 3.98 a$ & $6.41 \pm 0.52 a$ \\
\hline EDTA-Fe & $2.34 \pm 0.07 b$ & $0.41 \pm 0.03 c$ & $0.067 \pm 0.002 b$ & $19.21 \pm 1.64 b$ & $4.73 \pm 0.47 b c$ \\
\hline SA & $2.52 \pm 0.06 a$ & $0.47 \pm 0.01 c$ & $0.069 \pm 0.001 \mathrm{ab}$ & $21.99 \pm 3.71 b$ & $5.28 \pm 0.06 a b$ \\
\hline SNP & $2.52 \pm 0.16 a$ & $0.50 \pm 0.09 b c$ & $0.068 \pm 0.001 \mathrm{ab}$ & $19.93 \pm 1.93 b$ & $4.55 \pm 1.31 b c$ \\
\hline SA+SNP & $2.58 \pm 0.03 a$ & $0.64 \pm 0.04 a$ & $0.071 \pm 0.001 a$ & $17.31 \pm 0.87 b$ & $3.50 \pm 0.32 c$ \\
\hline $1 / 2(S A+S N P)$ & $2.52 \pm 0.05 a$ & $0.57 \pm 0.06 a b$ & $0.069 \pm 0.002 \mathrm{ab}$ & $18.77 \pm 2.67 b$ & $4.40 \pm 1.53 b c$ \\
\hline
\end{tabular}

CK: hydroponic systems; EDTA-Fe: Hoagland nutrient solution containing $0.1 \mathrm{mM}$ EDTA-Fe; SA: hydroponic systems and foliar application of 1.0 mM SA; SNP: hydroponic systems and foliar application of $2.5 \mathrm{mM} \mathrm{SNP}$; SA+SNP: hydroponic systems and foliar application of $1.0 \mathrm{mM}$ SA and $2.5 \mathrm{mM}$ SNP; $1 / 2$ (SA+SNP): hydroponic systems and foliar application of $0.5 \mathrm{mM} \mathrm{SA}$ and $1.25 \mathrm{mM}$ SNP. Different lower case letters in the same line indicate a significant difference $(P<0.05)$ between different treatments. Data are means \pm SD of three replicate samples per treatment.

possibly reveal the last phases of hormone controlled growth realization. In the experiment, the activities of $\mathrm{H}^{+}$-ATPase and FCR were significantly increased in roots by foliar application of SA and/or SNP, leading to the nutrient solution $\mathrm{pH}$ reduced and total Fe concentrations increased in roots. Moreover, the Fe concentration in the cell wall in roots was decreased and the Fe concentrations in the soluble fraction and cell organelles in roots were increased by foliar application of SA+SNP. In addition, foliar application of SA+SNP also dramatically increased the $\mathrm{Fe}$ concentrations in the roots, stems and leaves of peanut compared with control. Therefore, we can infer that SA+SNP improved the uptake and translocation of Fe. Since the monocropped peanut suffers from less $\mathrm{Fe}$ availability, peanut under monocropping changes the expression of Fe-responsive genes, such as AhIRT1, encoding an iron-uptake transporter (Ding et al. 2010), and AhFRO1, encoding ferricchelate reductase (Ding et al. 2009). Peanut under Fe deficiency may be also changed AhIRT1 and AhFRO1 to improve Fe absorption and transportation in the experiment. However, when $\mathrm{Fe}$ availability is under a threshold level, those are not sufficient to support the Fe requirement for plant development, and the stress symptoms become evident. Exogenous application of $\mathrm{SA}+\mathrm{SNP}$ increased the Fe concentrations in peanut roots, stems and leaves compared with Fe deficiency treatment. Whether this is because SA+SNP changed AhIRT1 and AhFRO1 improving Fe absorption and transportation or not is needed further research.

Fe deficiency significantly decreased the net photosynthesis (Table 3; Zhang et al. 2012). The factors mainly include stomatal limitation caused by stomatal closure and non-stomatal limitation. The former may be caused by several factors, including the decline of essential nutrient elements content, especially $\mathrm{K}$, and the increased production of ROS in chloroplasts. The latter may be caused by Fe deficiency decreased active Fe content. Under our experimental conditions, the ionic homeostasis was greatly disturbed (Figure 3) and active Fe content was dramatically decreased (Table 4) by Fe deficiency. In addition, chlorophyll content and chlorophyll fluorescence are considered as indicators of damages to photosynthetic system induced by environmental stressors (Maxwell and Johnson 2000; Shi et al. 2009). As we all know, Fe is involved in chlorophyll biosynthesis. Therefore, Fe deficiency impairs chlorophyll biosynthesis and chloroplast development, where the photosynthesis in plants predominantly relies on the green leaf, and its productivity directly depends upon the chlorophyll bearing surface area, irradiance and its potential to utilize $\mathrm{CO}_{2}$. However, foliar application of SA and/or SNP stimulated the maintenance of ions disturbed by $\mathrm{Fe}$ deficiency. Bush (1993) has clearly established that $\mathrm{Ca}^{2+}$ acts as an intracellular messenger in coupling a wide range of extracellular signals to specific responses. In the present study, SA and/or SNP increased $\mathrm{Ca}^{2+}$-ATPase activity in roots and significantly increased $\mathrm{Ca}^{2+}$ concentration in leaves (Figure 3D). Earlier studies indicated that exogenous SA treatment stimulated root formation and increased mineral uptake by plants (Khan et al. 2003; Yildirim et al. 2008). In addition, SA has long been known as a signal molecule in the induction of defense mechanisms in plants (Horvath et al. 2007) and probably modulated the total amylase activity and a-amylase activity by hormonal regulation (He et al. 2010). This is why the role of SA on membrane leakage, lipid peroxidation, and mineral uptake under stress conditions is important (Gunes et al. 2007). This positive effect of SA and SNP could be attributed to enhanced $\mathrm{CO}_{2}$ assimilation, active Fe content, chlorophyll concentration, and photosynthetic rate, which protected photosynthesis system.

In plants, there are several reports which show metalinduced alterations in both the activities of antioxidative 


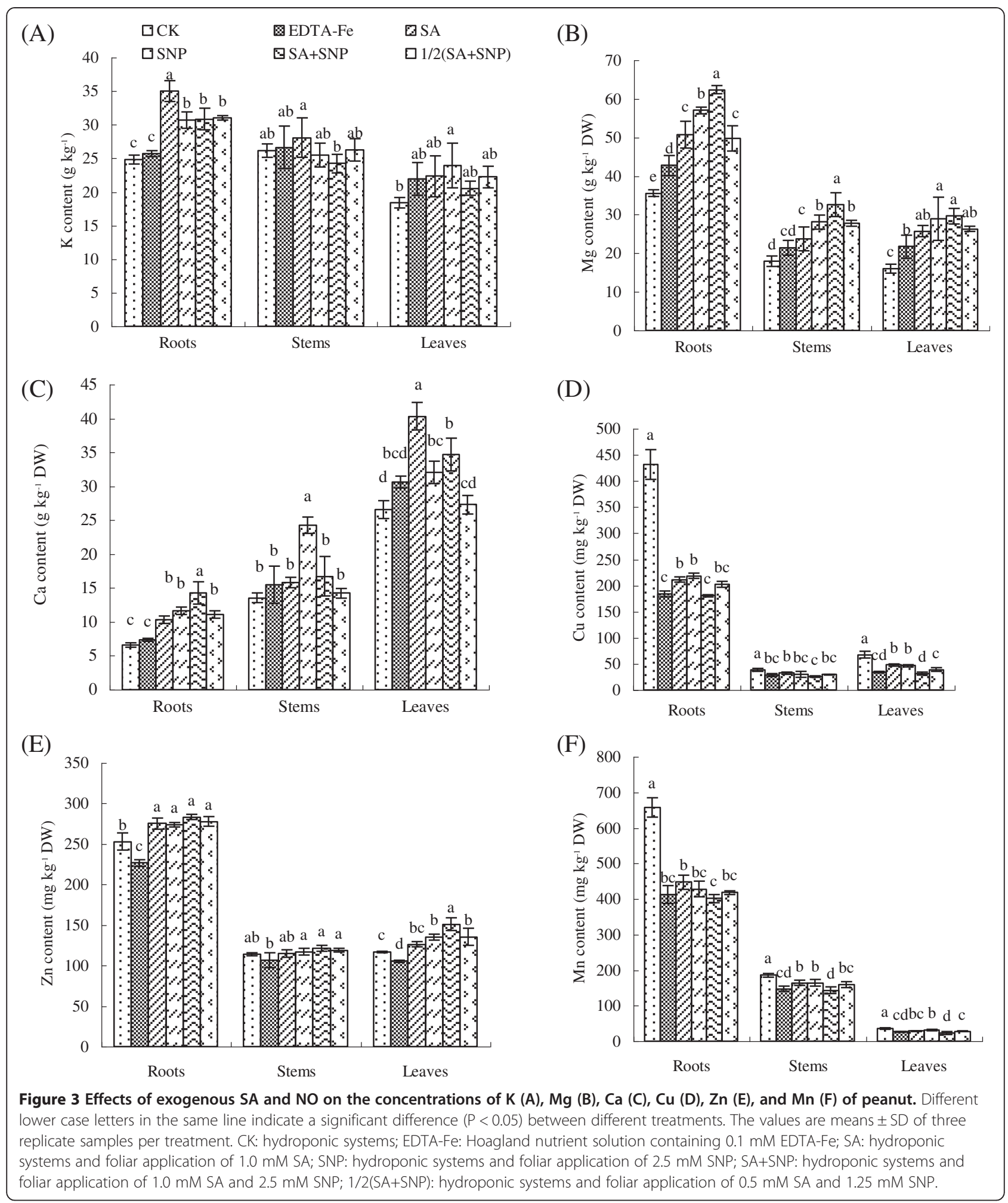

enzymes and the level of soluble antioxidants (Cakmak and Marschner 1992; Guo et al. 2007), accompanied by an enhancement of lipid peroxidation (Shi and Zhu 2008; Shi et al. 2009). Depending on its concentration,
Fe deficiency can impair the electron transport and may lead to the production of ROS (Graziano and Lamattina 2005). The overproduction of ROS can lead to oxidative injury such as membrane lipid peroxidation, protein 
oxidation, enzyme inhibition and DNA and RNA damage (Mittler 2002). In our experiments, Fe deficiencyinduced oxidative stress in peanut plants was evident to the increased MDA content and the $\mathrm{O}_{2}{ }^{\circ-}$ generation rate (Table 5). In normal physiological conditions, ROS keeps a dynamic balance between constantly produced and cleared. However, the balance was destroyed and the production of toxic oxygen derivatives was increased as a result of Fe deficiency stress. Fe deficiency increased SOD activity to convert the $\mathrm{O}_{2}{ }^{\cdot-}$ radical to the $\mathrm{H}_{2} \mathrm{O}_{2}$. However, it decreased POD and CAT activities. POD and CAT are all heme-containing enzymes and their activities are likely to be affected by Fe deficiency. Therefore, in the study, SA and/or SNP increased active Fe content (Table 4) and also increased the activities of POD and CAT. SA and/or SNP treatment increased the activities of antioxidant enzymes and reduced the adverse effect of ROS on amylase activity under Fe deficiency stress. Our findings indicated that SA and SNP act as plant growth regulators that can alleviate oxidative damage induced by Fe deficiency. These results are in agreement with recent researches (Simaei et al. 2011). Foliar application of exogenous SA or SNP, it also could alleviate the Fe deficiency induced chlorosis. However, the effects of SA+SNP were better than SA or SNP alone, or $1 / 2(\mathrm{SA}+\mathrm{SNP})$. This may be because $\mathrm{SA}+\mathrm{SNP}$ made the concentration of SA and NO in the plant body achieve the best level, so as to considerably alleviated chlorosis induced by Fe deficiency.

\section{Conclusions}

The present work demonstrates that SA and SNP can alleviate Fe deficiency-induced chlorosis separately or together. Additionally, the combination of SA and SNP in alleviating chlorosis is better than SA or SNP alone, but an appropriate concentration of SA and SNP was needed. The mechanism of SA and/or SNP alleviating Fe-deficiency induced chlorosis mainly contains: (1) promoted Fe uptake, translocation and activation, (2) modulated the balance of mineral elements, (3) protected $\mathrm{Fe}$ deficiency induced oxidative stress. Our results may serve as an integrated and optimized management strategy to alleviate Fe deficiency in peanuts production, but further study is needed.

\footnotetext{
Abbreviations

Ca: Calcium; Car: Carotenoids; CAT: Catalase; Chl: Chlorophyll; Cu: Copper; FCR: Fe ${ }^{(I I I)}$-Chelate Reductase; Fe: Iron; Fo: The minimal fluorescence; Fv/Fm: Maximal quantum yield of PS II; MDA: Malondialdehyde; Mg: Magnesium; Mn: Manganese; $\mathrm{O}_{2}{ }^{\cdot-}$ : Superoxide anion; $\mathrm{Pn}$ : Net photosynthetic; POD: Peroxidases; DPSII: The effective quantum yield of PS II; SNP: Sodium nitroprusside; SA: Salicylic acid; SOD: Superoxide dismutase; Tr: Transpiration rates; Zn: Zinc.
}

\section{Competing interests}

The authors declare that they have no competing interests.

\section{Authors' contributions}

$\mathrm{KJ}, \mathrm{XLL}, \mathrm{LS}$ and $\mathrm{BXY}$ are responsible for growth of the plants, stress applications, sampling, physiological and biochemical analysis and data analysis. DYJ KJ supplied all laboratory and chemical substances used in this study conceived of the study. $\mathrm{KJ}$ designed the experiment and also drafted the manuscript. All authors read and approved the final manuscript.

\section{Acknowledgments}

The authors thank English Lecturer Mr Stuart Craig MA (England, Taishan University of china) and English lecturer Xiujuan Wang (College of Foreign Languages, Shandong Agricultural University) for their critical reading and revision of the manuscript. We also thank Pingping Yang, College of Animal Science and Technology, Shandong Agricultural University, China, for her supplying instruments and patient guidance. Special acknowledgements are given to the editors and reviewers. This research was funded by Shandong Provincial Natural Science Foundation of China (ZR2013CM003).

Received: 22 September 2013 Accepted: 7 November 2013 Published: 20 January 2014

\section{References}

Bradford MM (1976) A rapid and sensitive method for the quantification of microgram quantities of protein utilizing the principle of protein-dye binding. Annu Rev Biochem 72:248-254

Briskin DP, Leonard RT, Hodges TK (1987) Isolation of the plasma membrane: markers and general principles. Method Enzymol 148:542-558, doi:10.1016/ 0076-6879(87)48053-1

Buchanan BB, Gruissem W, Jones RL (2000) Biochemistry and Molecular Biology of Plants. American Society of Plant Physiologists, Rockville, MD. ISBN 978-0-943088-39-6

Bush DS (1993) Regulation of cytosolic calcium in plants. Plant Physiol 103:7-13

Cakmak I, Marschner H (1992) Magnesium deficiency and high light intensity enhance activities of superoxide dismutase, ascorbate peroxidase, and glutathione reductase in bean leaves. Plant Physiol 98:1222-1227

Chen WW, Yang JL, Qin C, Jin CW, Mo JH, Ye T, Zheng SJ (2010) Nitric Oxide acts downstream of auxin to trigger root ferric-chelate reductase activity in response to iron deficiency in Arabidopsis. Plant Physiol 154:810-819, doi:10.1104/pp.110.161109

Ding F, Wang XF, Shi QH, Wang ML, Yang FJ, Gao QH (2008) Exogenous nitric oxide alleviated the inhibition of photosynthesis and antioxidant enzyme activities in iron-deficient chinese cabbage (Brassica chinensis L.). Agric Sci China 7:168-179

Ding H, Duan L, Wu H, Yang R, Ling H, Li WX, Zhang F (2009) Regulation of AhFRO1, an Fe(III)-chelate reductase of peanut, during iron deficiency stress and intercropping with maize. Physiol Plant 136:274-283, doi:10.1111/ j.1399-3054.2009.01219.x

Ding H, Duan LH, Li F, Yan HF, Zhao M, Zhang FS, Li WX (2010) Cloning and functional analysis of the peanut iron transporter AhIRT1 during iron deficiency stress and intercropping with maize. J Plant Physiol 167:996-1002, doi.org/10.1016/j.jplph.2009.12.019

El-Tayeb MA (2005) Response of barley grains to the interactive effect of salinity and salicylic acid. Plant Growth Regul 45:215-224, doi:10.1007/ s10725-005-4928-1

El-Tayeb MA, El-Enany AE, Ahmed NL (2006) Salicylic acid-induced adaptive response to copper stress in sunflower (Helianthus annuus L.). Plant Growth Regul 50:191-199, doi:10.1007/s10725-006-9118-2

Farooq M, Basra SMA, Wahid A, Rehman H (2009) Exogenously applied nitric oxide enhances the drought tolerance in fine grain aromatic rice (Oryza sativa L.). J Agronomy \& Crop Science 195:254-261, doi:10.1111/j.1439037X.2009.00367.X

Frédéric G, Duby G, Stedingk EV, Zhao RM, Morsomme P, Boutry M (2007) Expression of a constitutively activated plasma membrane $\mathrm{H}^{+}$-ATPase alters plant development and increases salt tolerance. Plant Physiol 144:1763-1776, doi:10.1104/pp.107.103762

Gao L, Shi YX (2007) Genetic differences in resistance to iron deficiency chlorosis in peanut. J Plant Nutr 30:37-52, doi:10.1080/01904160601054965

Graziano M, Lamattina L (2005) Nitric oxide and iron in plants: an emerging and converging story. Trends Plant Sci 10:4-8, doi:10.1016/j.tplants.2004.12.004

Graziano M, Lamattina L (2007) Nitric oxide accumulation is required for molecular and physiological responses to iron deficiency in tomato roots. Plant J 52:949-960, doi:10.1016/S0925-8388(97)00457-X 
Graziano M, Beligni MV, Lamattina L (2002) Nitric oxide improves internal iron availability in plants. Plant Physiol 130:1852-1859, http://dx.doi.org/10.1104/ pp.009076

Gunes A, Inal A, Alpaslan M, Eraslan F, Bagci EG, Cicek N (2007) Salicylic acid induced changes on some physiological parameters symptomatic for oxidative stress and mineral nutrition in maize (Zea mays L.) grown under salinity. J Plant Physiol 164:728-736, doi:10.1016/j.jplph.2005.12.009

Guo B, Liang YC, Zhu YG, Zhao FJ (2007) Role of salicylic acid in alleviating oxidative damage in rice roots (Oryza sativa) subjected to cadmium stress. Environ Pollut 147:743-749, doi:10.1016/j.envpol.2006.09.007

Hager A (2003) Role of the plasma membrane $\mathrm{H}^{+}$-ATPase in auxin-induced elongation growth: historical and new aspects. Journal of Plant Res 116:483-505, doi:10.1007/s10265-003-0110-x

Hakan CA, Vahap K (2007) Some parameters in relation to iron nutrition status of Peach Orchads. J Biol Environ Sci 1:111-115

He JY, Ren YF, Pan XB, Yan YP, Zhu C, Jiang D (2010) Salicylic acid alleviates the toxicity effect of cadmium on germination, seedling growth, and amylase activity of rice. J Plant Nutr Soil Sci 173:300-305, doi:10.1002/jpln.200800302

Heath RL, Packer L (1968) Photoperoxidation in isolated chloroplasts. I. Kinetics and stoichiometry of fatty acid peroxidation. Arch Biochem Biophys 125:189-198, doi:10.1016/0003-9861(68)90654-1

Hoagland DR, Arnon DI (1950) The water culture method for growing plants without soil. Circular. Calif AES 347:29-32

Horvath E, Szalai S, Janda T (2007) Induction of abiotic stress tolerance by salicylic acid signaling. J Plant Growth Regul 26:290-300, doi:10.1007/s00344007-9017-4

Hu KD, Hu LY, Li YH, Zhang FQ, Zhang H (2007) Protective roles of nitric oxide on germination and antioxidant metabolism in wheat seeds under copper stress. Plant Growth Regul 53:173-183, doi:10.1007/s10725-007-9216-9

Jin CW, He XY, Wu P, Zheng SJ (2006) Mechanisms of microbially enhanced Fe acquisition in red clover (Trifolium pretense L.). Plant Cell Environ 29:888-897, doi:10.1111/j.1365-3040.2005.01468.x

Jin CW, You GY, He YF, Tang CX, Wu P, Zheng SJ (2007) Iron deficiency-Induced secretion of phenolics facilitates the reutilization of root apoplastic iron in red clover. Plant Physiol 144:278-285, doi:10.1104/pp.107.095794

Karlidag H, Yildirim E, Turan M (2009) Exogenous applications of salicylic acid affect quality and yield of strawberry grown under antifrost heated greenhouse conditions. J Plant Nutr Soil Sci 172:270-276, doi:10.1002/ jpln.200800058

Kazemi N, Khavari-Nejad RA, Fahimi H, Saadatmand S, Nejad-Sattari T (2010) Effects of exogenous salicylic acid and nitric oxide on lipid peroxidation and antioxidant enzyme activities in leaves of Brassica napus L. under nickel stress. Sci Hortic-amsterdam 126:402-407, doi:10.1016/j.scienta2010.07.037

Khan W, Prithiviraj B, Smith DL (2003) Photosynthetic responses of corn and soybean to foliar application of salicylates. J Plant Physiol 160:485-492, doi:10.1078/0176-1617-00865

Khodary SEA (2004) Effect of salicylic acid on the growth, photosynthesis and carbohydrate metabolism in salt-stressed maize plants. Int J Agric Biol 6:5-8

Klessig DF, Durner J, Noad R, Navarre DA, Wendehenne D, Kumar D, Zhou JM, Shali S, Zhang S, Kachroo P, Trifa Y, Pontier D, Lam E, Silva H (2000) Nitric oxide and salicylic acid signaling in plant defense. Proc Natl Acad Sci U S A 97:8849-8855, doi:10.1073/pnas.97.16.8849

Knudson LL, Tibbitts TW, Edwards GE (1977) Measurement of ozone injury by determination of leaf chlorophyll concentration. Plant Physiol 60:606-608, doi:10.1104/pp.60.4.606

Ligaba A, Yamaguchi M, Shen H, Sasaki T, Yamamoto Y, Matsumoto H (2004) Phosphorus deficiency enhances plasma membrane $\mathrm{H}+-$ ATPase activity and citrate exudation in greater purple lupin (Lupinus pilosus). Funct Plant Biol 31:1075-1083, doi:10.1071/FP04091

Maxwell K, Johnson GN (2000) Chlorophyll fluorescence-a practical guide. J Exp Bot 51:659-668, doi:10.1093/jexbot/51.345.659

Metwally A, Finkemeier I, George M, Dietz K (2003) Salicylic acid alleviates the cadmium toxicity in barley seedings. Plant Physiol 132:272-281, doi:10.1104/ pp.102.018457

Mittler R (2002) Oxidative stress, antioxidants and stress tolerance. Trends Plant Sci 7:405-410, doi:10.1016/s1360-1385(02)02312-9

Molassiotis A, Therios I, Dimassi K, Diamantidis G, Chatzissavvidis C (2005) Induction of $\mathrm{Fe}(\mathrm{III})$-chelate reductase activity by ethylene and salicylic acid in iron-deficient peach rootstock explants. J Plant Nutr 28:669-682, doi:10.1081/PLN-200052641
Morales F, Belkhodja R, Abadía A, Abadía J (2000) Photosystem II efficiency and mechanisms of energy dissipation in iron-deficient, field-grown pear trees (Pyrus communis L.). Photosynth Res 63:9-21, doi:10.1023/A.1006389915424

Nickel KS, Cunningham BA (1969) Improved peroxidase assay method using Leuco 2,3,6-trichloro indophenol and application to comparative measurements of peroxidase catalysis. Ann Clin Biochem 27:292-299

Ohinishi T, Gall RS, Mayer ML (1975) An improved assay of inorganic phosphate in the presence of extralabile phosphate compounds: application to the ATP-ase assay in the presence of phosphocreatine. Anal Biochem 69:261-267

Osses LR, Godoy CA (2006) Characterizing plasma membrane $\mathrm{H}^{+}$-ATPase in two varieties of coffee leaf (Coffea arabica L.) and its interaction with an elicitor fraction from the orange rust fungus $(\mathrm{H}$. Vastatrix Berk and Br.) race II. Plant Physiol Bioch 44:226-235, doi:10.1016/j.plaphy.2006.01.009

Rao KVM, Sresty TVS (2000) Antioxidative parameters in the seedlings of pigeon pea (Cajanus cajan L. Millspaugh) in response to Zn and Ni stresses. Plant Sci 157:113-128, doi:10.1016/s0168-9452(00)00273-9

Raskin I (1992) Role of salicylic acid in plants. Ann Rev Plant Physiol Mol Bio 43:439-463, doi:10.1146/annurev.pp.43.060192.002255

Santi S, Schmidt W (2009) Dissecting iron deficiency-induced proton extrusion in Arabidopsis roots. New Phytol 183:1072-1084, doi:10.1111/j.14698137.2009.02908.x

Shi QH, Zhu ZJ (2008) Effects of exogenous salicylic acid on manganese toxicity, element contents and antioxidative system in cucumber. Environ Exp Bot 63:317-326, doi:10.1016/j.envexpbot.2007.11.003

Shi GR, Cai QS, Liu QQ, Wu L (2009) Salicylic acid-mediated alleviation of cadmium toxicity in hemp plants in relation to cadmium uptake, photosynthesis, and antioxidant enzymes. Acta Physio Plant 31:969-977, doi:10.1007/s11738-009-0312-5

Simaei M, Khavarinejad RA, Saadatmand S, Bernard F, Fahimi H (2011) Interactive effects of salicylic acid and nitric oxide on soybean plants under $\mathrm{NaCl}$ salinity. Russ J Plant Physiol 58:783-790, doi:10.1134/s1021443711050220 pp. 783-790

Sun BT, Jing Y, Chen KM, Song LL, Chen FJ, Zhang LX (2007) Protective effect of nitric oxide on iron deficiency-induced oxidative stress in maize (Zea mays). J Plant Physiol 164:536-543, doi:10.1016/j.jplph.2006.02.011

Vert G, Grotz N, Dedaldechamp F, Gaymard F, Guerinot ML, Briat JF, Curie C (2002) IRT1, an Arabidopsis transporter essential for iron uptake from the soil and for plant growth. Plant Cell 14:1223-1233, doi:10.1105/tpc.001388

Yildirim E, Turan M, Guvenc I (2008) Effect of foliar salicylic acid applications on growth, chlorophyll and mineral content of cucumber (Cucumis sativus L.) grown under salt stress. J Plant Nutr 31:593-612

Zhang XW, Zhang M, Wang QH, Qiu XK, Hu GQ, Dong YJ (2011) Effect of exogenous nitric oxide on physiological characteristic of peanut under irondeficient stress. J Plant Nutr and Fert 17:665-673, http://www.plantnutrifert. org/CN/abstract/abstract2705.shtml

Zhang XW, Dong YJ, Qiu XK, Hu GQ, Wang YH, Wang QH (2012) Exogenous nitric oxide alleviates iron-deficiency chlorosis in peanut growing on calcareous soil. Plant Soil Environ 58:111-120

Zottini M, Costa A, Michele RD, Ruzzene M, Carimi F, Schiavo FL (2007) Salicylic acid activates nitric oxide synthesis in Arabidopsis. J Exp Bot 58:1397-1405, doi:10.1093/jxb/erm001

Zuo YM, Zhang FS, Li XL, Cao YP (2000) Studies on the improvement in iron nutrition of peanut by intercropping with maize on a calcareous soil. Plant Soil 220:13-25, doi:10.1023/A:1004724219988

\section{doi:10.1186/1999-3110-55-9}

Cite this article as: Kong et al: Effects of foliar application of salicylic acid and nitric oxide in alleviating iron deficiency induced chlorosis of Arachis hypogaea L.. Botanical Studies 2014 55:9. 